\title{
ARAŞTIRMA / RESEARCH \\ Quantitative computerized tomography evaluation of the effects of COVID-19 pneumonia on lung volume
}

COVID-19 pnömonisinin akciğer hacmi üzerindeki etkilerinin kantitatif bilgisayarlı tomografi ile değerlendirilmesi

\author{
Ayşe Özlem Balık1 id, Buket Yağc1 ${ }^{1}$ id
}

${ }^{1}$ Haydarpaşa Numune Training and Research Hospital, Department of Radiology, Istanbul, Turkey

\author{
Cukurova Medical Journal 2022;47(1):415-425
}

\begin{abstract}
Purpose: The aim of this study was o assess the relationship between lung volume decrease and computed tomography (CT) findings in patients with COVID-19 pneumonia in early period.

Materials and Methods: Fifty-four patients were included in the study. The lung volume (LV) was calculated separately for each lung by software-based quantitative CT (QCT). Patient demographics, comorbidity and smoking status, CT findings, visual semi-quantitative CT severity scoring (CT-SS), and decrease of LV were analyzed.

Results: The rate of volume decrease was not statistically related to, age, gender, smoking, or hospitalization status. When the correlation between follow-up CT (FUCT) LV and CT-SS was examined there were good inverse correlation on the right lung $(\mathrm{r}=-0.583 ; \mathrm{p}=0.001)$ and left lung $(\mathrm{r}=-0.478 ; \mathrm{p}=0.001)$. The rate of decrease in the right LV was significantly higher in patients with comorbidities compared to other patients. There was a statistically moderate inverse correlation between decrease of LV and CT-SS in the right lung $(r=-0.294 ; p=0.031)$, and no significant correlation was found between the decrease of LV and CT-SS in the left lung $(\mathrm{r}=-0.096$; $\mathrm{p}=$ 0.489).

Conclusion: The rate of lung damage and associated volume decrease both increase with the amount of parenchymal involvement in patients with COVID-19 pneumonia. This change is more frequent in patients with multiple comorbidities. Accurate interpretation of CT findings with quantitative data can help physicians to manage the disease.
\end{abstract}

Keywords: COVID-19, lung volume measurements, multidetector computed tomography, quantitative, pulmonary fibrosis.
Öz

Amaç: Bu çalışmanın amacı COVID-19 pnömonisi olan hastalarda erken dönemde akciğer hacim azalması ile bilgisayarlı tomografi (BT) bulguları arasındaki ilişkiyi değerlendirmektir.

Gereç ve Yöntem: Çalışmaya inceleme kriterlerini karşılayan elli dört hasta dahil edildi. Hastaların her bir akciğeri için yazılım tabanlı kantitatif BT ile ölçüm yapılarak akciğer hacimleri hesaplandı. Hastalara ait demografik veriler, komorbidite ve sigara içme durumu, BT'deki inflamasyon bulguları, akciğer parankimindeki tutulum miktarını gösteren BT şiddet skorlaması ile ilk ve takip BT"lerindeki akciğer hacmindeki değissiklikler (azalma) arasındaki ilişki değerlendirildi.

Bulgular: Hacim azalma oranı, yaş, cinsiyet, sigara içme veya hastanede yatış durumu ile istatistiksel olarak ilişkili değildi. Takip BT lerinde akciğer hacmi ve ciddiyet skorlaması arasındaki korelasyon incelendiğinde, sağ akciğerde $(\mathrm{r}=-0.583 ; \mathrm{p}=0.001)$ ve sol akciğerde $(\mathrm{r}=$ $0.478 ; \mathrm{p}=0.001)$ iyi derecede ters korelasyon vardı. Sağ akciğer hacmindeki azalma oranı komorbiditesi olan hastalarda diğer hastalara göre anlamlı derecede yüksekti. Sağ akciğerde hacim kaybı ile ciddiyet skoru arasında istatistiksel olarak orta derecede ters korelasyon varken ( $\mathrm{r}$ $=-0.294 ; \mathrm{p}=0.031)$ ve sol akciğerde anlamlı bir korelasyon bulunmadi $(r=-0.096 ; \mathrm{p}=0.489)$.

Sonuç: COVID-19 pnömonisi olan hastalarda parankimal tutulum miktarı ile birlikte akciğer hasarı oranı ve buna bağlı hacim azalması artar. Bu değişiklik komorbiditesi olanlarda daha sık görülmektedir. BT bulgularının nicel verilerle doğru yorumlanması, hekimlerin hastalı̆̆1 yönetmesine yardımcı olabilir.

Anahtar kelimeler: COVID-19 virüs, akciğer volüm ölçümleri, çok kesitli bilgisayarlı tomografi, kantitatif, pulmoner fibrozis. 


\section{INTRODUCTION}

In the second year of the severe acute respiratory syndrome coronavirus-2 (SARS-CoV-2) pandemic, the global scientific community is still investigating the effects of the virus on the human body. Currently, the genetic and molecular studies continue to investigate why the virus affects some individuals much more severely than others. In particular, the detrimental long term effects of the virus on the lungs are receiving widespread attention by the scientific community. It is well known that the lung is the most frequently involved organ in COVID-19 ${ }^{1}$. It is generally accepted that SARS-CoV-2 is related to fibrotic changes which ultimately leads to pulmonary fibrosis (PF), lung collapse, multi-organ failure, and mortality in the severe cases ${ }^{2}$.

It has been demonstrated that inflammation leads to alveolar epithelial injury in long-term, which activates fibroblasts and myofibroblasts, causing excessive collagen deposition in the extracellular matrix ${ }^{3}$. Computed tomography (CT) plays an important role in early diagnosis and treatment decision in the light of histological changes that cause fibrosis. Linear opacities, reticular densities are the signs of fibrotic changes on CT images and are detected more common in the progressive stage (8-14 days after onset of symptoms) than in the early stage ( 7 days after onset of symptoms) ${ }^{4}$. It has been stated that the functional volume loss is observed with these inflammatory changes, accompanied by swelling of the infected lung tissue and filling of the alveoli with exudate $^{5}$. Recently a few reports and studies have been published showing that SARS-CoV-2 reduces lung volume on $\mathrm{CT}^{5-7}$.

In their seminal paper of Iwasava et al. demonstrated that smaller CT lung volume in severe cases. They related this volume loss to alveolar collapse, which is commonly accompanying to $\mathrm{ARDS}^{8}$. CT measures of lung volume change in idiopathic pulmonary fibrosis correlate strongly with lung volume characteristics measured by pulmonary function tests?

We hypothesize that lung volume tends to decrease in follow-up QCT of patients with severe COVID19 pneumonia and this may be associated with older age, comorbidity, and density of fibrotic CT findings. To our knowledge of whether LV loss related fibrotic changes or a sever disease is largely based on very limited data.
Based on this knowledge, lung volumes were measured by QCT analysis. The purpose of this study is to explore the relationship between LV decrease and CT findings in patients with COVID-19 pneumonia in early period.

\section{MATERIALS AND METHODS}

This cross-sectional retrospective study was approved by the Haydarpaşa Numune Training and Research Hospital Clinical Research Ethics Committee, and conducted in accordance with the ethical principles for medical research involving human subjects, outlined in the Helsinki Declaration (Approval number of the ethics committee: 2020/KK/201-2927- 10.12.2020). Written informed consent was obtained from all of the patients.

\section{Study population}

We investigated 285 clinically diagnosed pneumonia patients who tested positive in pharyngeal swab nucleic acid testing (RT-PCR test) for COVID-19 in our hospital between March 15-April 30, 2020. The initial CTs (ICT) were obtained within 2 days after the PCR test. Of 285 patients, sixty-eight had at least one follow-up CT (FUCT). A total of fifty-four patients (31 males, 54.4\%) were included (Figure 1). Patients younger than 18 years of age, patients who could not hold their breath during CT scans and causing severe artifacts on images, and patients with massive pleural effusions (because of its compressive effect) were excluded from the study.

Patient demographics including age, gender, comorbidity, and smoking status, were assumed from the DICOM headers of the CT scans or patient records within the hospital information system (HIS) or phone calls. The Picture Archiving and Diagnostic System (PACS) was scanned to find out the patient's hospitalization status and the chest radiographs were evaluated to determine whether the patients were mechanically ventilated. Patients were divided into two groups according to the hospitalization status: the outpatient group and hospitalized group.

\section{Image interpretation}

All CT scans were performed with a 64-section multidetector CT (General Electric Healthcare Optima CT 520, USA) allocated for patients with suspected COVID-19 during the pandemic. The same device 
was used for initial, and follow-up examinations and the images were acquired using the following parameters: $100 \mathrm{kV}, 120 \mathrm{~mA}$, detector coverage: 40.0 $\mathrm{mm}$, helical thickness: $5.0 \mathrm{~mm}$, pitch, and speed $(\mathrm{mm} / \mathrm{rot})$ of $1.531: 1$ and 61.25 respectively, and rotation time: 0.5 seconds. In all patients, CT examinations were performed in the supine position at the end-inspiratory phase during breath-hold.
Breath training was provided before CT evaluation to reduce motion artifacts. The images were reconstructed using the lung (width: 1000-1400 HU, level: $750 \mathrm{HU}$ ) and mediastinal windows (width, 350 $\mathrm{HU}$; level, 35-40 HU). All follow-up images were obtained using the same protocol as the initial images. The mean interval between ICT and the FUCT examinations was $10.50 \pm 2.83$ days (7-14 days).

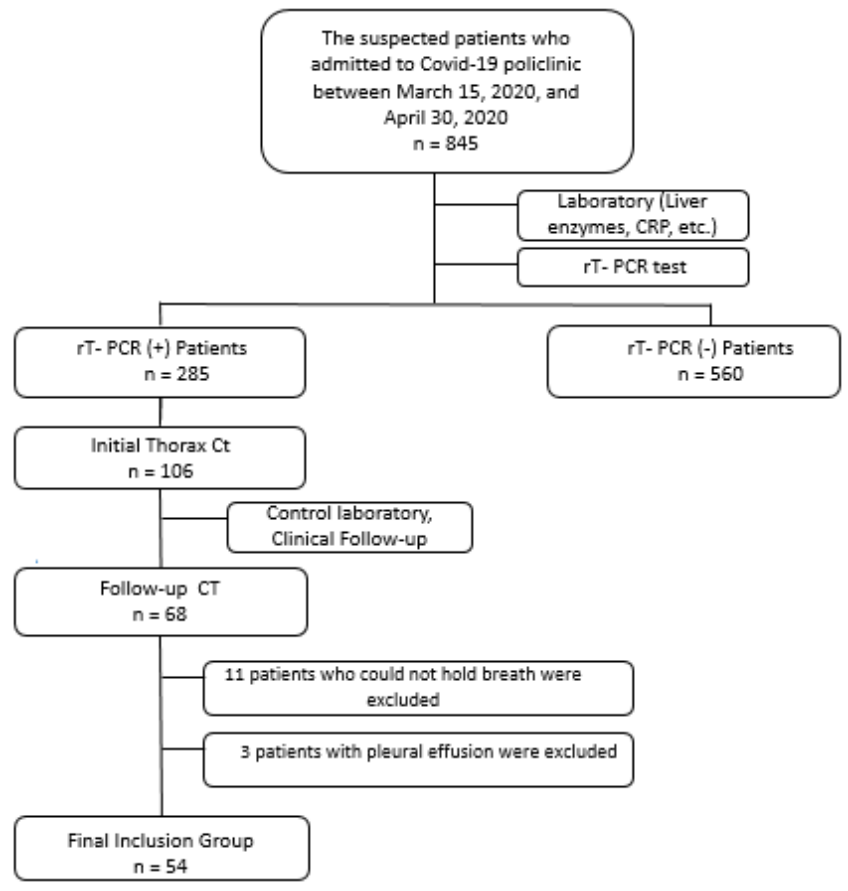

Figure 1. Flowchart shows procedures performed to COVID- 19 pneumonia patients and exclusion criteria.

Follow-up CT was generally performed to patients who had progressing respiratory symptoms or increasing involvement in chest X-ray (CXR) images. The initial and follow-up CT images were retrospectively reviewed by two radiologists with 17 and 4 years of experience in thoracic radiology, respectively. After individual assessments, any disagreements were resolved through discussion and consensus. First, lesions were categorized by distribution as central, peripheral, or both in the involved segments. Subsequently, the main pattern of involvement was characterized as the predominant presence of ground-glass opacity (GGO) (increased density without obscured vessels) or consolidation (obscured vessels and presence of air bronchograms). Additional findings were also recorded, such as the crazy-paving pattern (thickening of both interlobular septa and intralobular lines superimposed accompanied by GGO), linear opacities. ${ }^{10,11}$ And finally, the visual CT-SS proposed by Yang R. et al. was used to measure the degree of parenchymal involvement. The opacification degree of 20 lung segments was determined using a scoring system that provided values of 0,1 , and 2 if the opacification affected $0 \%$, less than $50 \%$, and more than $50 \%$ of the areas, respectively. ${ }^{12}$ An overall lung visual semiquantitative CT severity scoring (CT-SS) was reached by summing all the regions' scores (score range for one lung: $0-20$, maximum score for both lungs: 40). Using Vital's Vitrea ${ }^{\text {TM }}$ Advanced Visualization - postprocessing software, lung parenchyma volumes (LV) in ICT and FUCTs of patients were quantified 
separately for each lung (Version 7.0, Canon Medical Systems Cooperation, Otawara, Tochigi, Japan). Total lung parenchyma analysis was selected depending on attenuation values between -200 and -950 HU. The main bronchi, esophagus, and trachea were excluded automatically by software processing.

\section{Statistical analysis}

IBM SPSS Statistics 22 program was used for statistical analysis. Descriptive statistical methods (mean, standard deviation, median, frequency, ratio, minimum, maximum) were employed while evaluating the study data. The suitability of the quantitative data to normal distribution was evaluated by Kolmogorov-Smirnov and Shapiro-Wilk tests and graphical evaluations. Mann-Whitney U test was used for the comparison of the age, gender, smoking status, hospitalization status with lung volume decrease. The Pearson Chi-square test, FisherFreeman-Halton Exact test, and Fisher's Exact tests were used in the comparison of qualitative data such as gender, comorbidity status, smoking history, and treatment type to LV decrease. Relationships between CT-SS and LV decrease were evaluated using Spearman's correlation coefficient (r). A Spearman $r$ value of $0-0.20$ was considered weak, 0.20-0.40 moderate, 0.41-0.60 good, and 0.81-1.00 excellent correlation. A $\mathrm{P}$ value of $<0.05$ was considered statistically significant.

\section{RESULTS}

Fifty-four patients were included in this study. Table 1 shows the demographic and clinical data of the patients at the time of admission. Of the fifty-four patients, $40(74.1 \%)$ had evidence of pneumonia on ICT. The remaining fourteen patients had pneumonia findings on FUCT. GGO was the predominant pattern seen in forty cases $(74.1 \%)$ on ICT and $41(75.9 \%)$ on FUCT. Linear opacities were identified much more frequently than the other findings on FUCT ( $\mathrm{n}=19,35.2 \%, \mathrm{p}=0.035$ ). The peripheral distribution was seen on both ICT, and FUCT in $24(44.4 \%)$, and $28(51.9 \%)$ patients, respectively, but there was no statistically significant difference between the rates of this distribution type in each period $(\mathrm{p}=0.796)$.

Table 1. Demographic features, comorbidity, smoking status and treatment type of the patients

\begin{tabular}{|c|c|c|}
\hline \multirow{4}{*}{ Age, (Years), n (\%) } & Min.-Max. & $21-93(50)$ \\
\hline & Mean \pm SD & $49.65 \pm 16.87$ \\
\hline & $<55$ years & $36(66.7)$ \\
\hline & $\geq 55$ years & $18(33.3)$ \\
\hline \multirow{2}{*}{ Sex, n (\%) } & Male & $30(55.6)$ \\
\hline & Female & $24(44.4)$ \\
\hline \multirow{2}{*}{ Comorbidity, n (\%) } & Absent & $32(59.3)$ \\
\hline & Present & $22(40.7)$ \\
\hline \multirow{6}{*}{ Comorbidity type, n (\%) } & Hypertension & $11(20.4)$ \\
\hline & Type 2 D.M. & $10(18.5)$ \\
\hline & COPD & $5(9.3)$ \\
\hline & CAD & $6(11.1)$ \\
\hline & CRF & $1(1.9)$ \\
\hline & Malignity & $1(1.9)$ \\
\hline \multirow{3}{*}{ Smoking status, $(n=34)$} & Never & $21(61.8)$ \\
\hline & Current & $10(29.4)$ \\
\hline & Former & $3(8.8)$ \\
\hline \multirow[b]{2}{*}{ Treatment type, n (\%) } & Outpatient & $31(57.4)$ \\
\hline & Inpatient & $23(42.6)$ \\
\hline \multirow{2}{*}{ CT interval (Day) } & Min.-Max. (Median) & $7-14(9)$ \\
\hline & Mean \pm SD & $10.50 \pm 2.83$ \\
\hline
\end{tabular}

SD: Standard deviation, DM: Diabetes Mellitus, COPD: Chronic obstructive pulmonary disease, CAD: Coronary artery disease, CRY: Chronic renal failure.

The decrease in lung volumes in each lung was significant among all genders $(p<0.01)$, but there was no significant difference between male and female patients $(p>0.05)$. In fourteen patients 
without any findings on initial CTs, the lung volume decreased larger than those in other patients $(\mathrm{p}=$ 0.037). The right lung volume had significantly decreased in those under and over 55 years of age $(p$ $=0.001$, and $\mathrm{p}=0.028$, respectively) (Figure 2). The ILV values of both lungs were significantly lower in patients with comorbidities than in those without $(p$ $=0.022$, and $\mathrm{p}=0.024$ for right and left lungs, respectively). There was no significant difference between smokers and non-smokers regarding the decrease in lung volumes ( $p>0.05)$. ILV values were significantly lower for both lungs in the inpatient group compared to the outpatients $(\mathrm{p}=0.022$, and $\mathrm{p}$ $=0.011$ respectively); however, lung volume decrease was similar between these two groups ( $p>0.05)$.

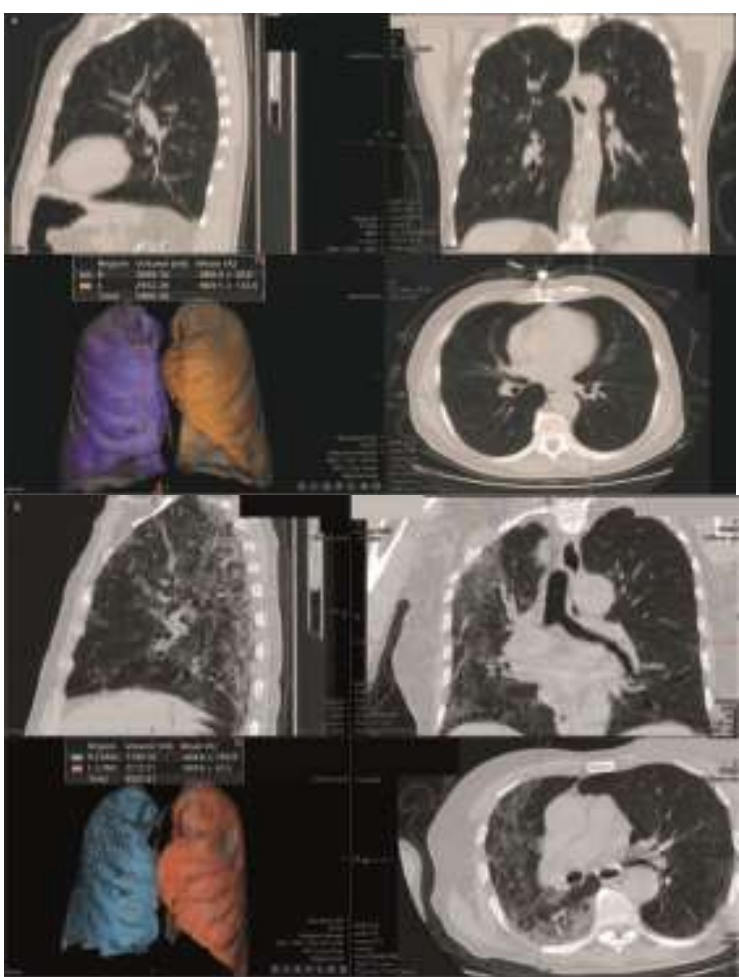

Figure 2. 72-year-old COVID-19 pneumonia patient's CT images of the initial evaluation lung parenchyma was normal and CT-SS was 0 (a). Follow-up CT scans performed 12 days later showed widespread parenchymal fibrotic bands, crazy-paving pattern, mediastinal shift to the right, and a dramatic decrease in right lung volume in post-processing images. Total CT-SS score was elevated to 24 (b).

There was a good inverse correlation between FUCT and CT-SS $(\mathrm{r}=-0.583 ; p=0.001)$ and a moderate inverse correlation between lung volume decrease and CT-SS in the right lung $(\mathrm{r}=-0.294 ; p=0.031$, respectively). There was a good inverse correlation between FUCT and CT-SS in the left lung $(r=-0.478$; $p=0.001)$ and no correlation was found between lung volume decrease and CT-SS in the left lung ( $\mathrm{r}=$ -0.096; $p=0.489$ ) (Figure 3, Table 2).
The volume decrease in these cases did not differ according to age, gender, and smoking status $(\phi>$ 0.05). However, the rate of decrease in the right lung volume was significantly higher among those with comorbidities compared to those without $(p<0.01)$. The rate of volume decrease for each lung was higher among patients with Type $2 \mathrm{DM}$ compared to all other patients $(p<0.05)$ (Figure 4 , Table 3 ). 
Table 2. Evaluation of lung volume decrease on CT according to descriptive features, smoking status, treatment status and CT-SS

\begin{tabular}{|c|c|c|c|c|}
\hline & & & Lung Vo & Decrease \\
\hline & & & Right Lung (mL) & Left Lung (mL) \\
\hline & Male & $\begin{array}{l}\text { Min.-Max. } \\
\text { (Median) }\end{array}$ & $-1344.9 / 551.8(-278.4)$ & $-1329.8 / 432.7(-179.4)$ \\
\hline Gender & & Mean \pm SD & $-288.40 \pm 418.06$ & $-240.16 \pm 413.42$ \\
\hline & & $\begin{array}{l}\text { Min.-Max. } \\
\text { (Median) }\end{array}$ & $-943.4 / 479.3(-263.3)$ & $-887.8 / 454.3(-129.3)$ \\
\hline & Female & Mean \pm SD & $-244.09 \pm 328.99$ & $-141.19 \pm 320.01$ \\
\hline & & $\mathrm{p}^{\mathrm{a}}$ & 0.903 & 0.384 \\
\hline & $<55$ & $\begin{array}{l}\text { Min.-Max. } \\
\text { (Median) }\end{array}$ & $-1344.9 / 551.8(-266.4)$ & $-1329.8 / 432.7(-147)$ \\
\hline Age & & Mean \pm SD & $-317.79 \pm 402.43$ & $-241.96 \pm 384.00$ \\
\hline & $>55$ & $\begin{array}{l}\text { Min.-Max. } \\
\text { (Median) }\end{array}$ & $-667.5 / 479.3(-268.1)$ & $-677.4 / 454.3(-52.7)$ \\
\hline & & Mean \pm SD & $-170.55 \pm 312.08$ & $-104.60 \pm 347.70$ \\
\hline & & $\mathrm{p}^{\mathrm{a}}$ & 0.279 & 0.263 \\
\hline Smoking & Never & $\begin{array}{l}\text { Min.-Max } \\
\text { (Median) }\end{array}$ & $-1344.9 / 531.4(-198.4)$ & $-1329.8 / 454.3(-100.9)$ \\
\hline status & & Mean \pm SD & $-235.29 \pm 422.81$ & $-214.82 \pm 414.16$ \\
\hline & $\begin{array}{l}\text { Former/ } \\
\text { Current }\end{array}$ & $\begin{array}{l}\text { Min.-Max } \\
\text { (Median) }\end{array}$ & $-667.5 / 12.3(-313.4)$ & $-898.2 / 422.8(-180.9)$ \\
\hline & & Mean \pm SD & $-307.16 \pm 214.07$ & $-231.72 \pm 344.57$ \\
\hline & & $\mathrm{p}^{\mathrm{a}}$ & 0.264 & 0.658 \\
\hline Hospitalization & Outpatient & $\begin{array}{l}\text { Min.-Max. } \\
\text { (Median) }\end{array}$ & $-1344.9 / 531.4(-180.3)$ & $-1329.8 / 365.5(-100.9)$ \\
\hline status & & Mean \pm SD & $-238.00 \pm 411.47$ & $-188.75 \pm 378.43$ \\
\hline & Hospitalized & $\begin{array}{l}\text { Min.-Max. } \\
\text { (Median) }\end{array}$ & $-1005.5 / 551.8(-300.3)$ & $-898.2 / 454.3(-178.4)$ \\
\hline & & Mean \pm SD & $-310.09 \pm 332.78$ & $-206.18 \pm 377.92$ \\
\hline & & $\mathrm{p}^{\mathrm{a}}$ & 0.238 & 0.468 \\
\hline & ICT score & $\mathrm{r}$ & -0.350 & -0.260 \\
\hline Relationship & & $\mathrm{p}$ & $0.009^{* *}$ & 0.058 \\
\hline CT-SS and lung & FUCT score & $\mathrm{r}$ & -0.583 & -0.478 \\
\hline volume & & $\mathrm{p}$ & $0.001^{* *}$ & $0.001^{* *}$ \\
\hline & CT-SS & $\mathrm{r}$ & -0.294 & -0.096 \\
\hline & differ & $\mathrm{p}$ & $0.031 *$ & 0.489 \\
\hline
\end{tabular}

${ }^{a}$ Mann-Whitney U Test r: Spearman's correlation coefficient $*_{p}<0.05$

Abbreviations: ICT: Initial CT, FUCT: Follow-up CT, CT-SS: CT severity scoring. 


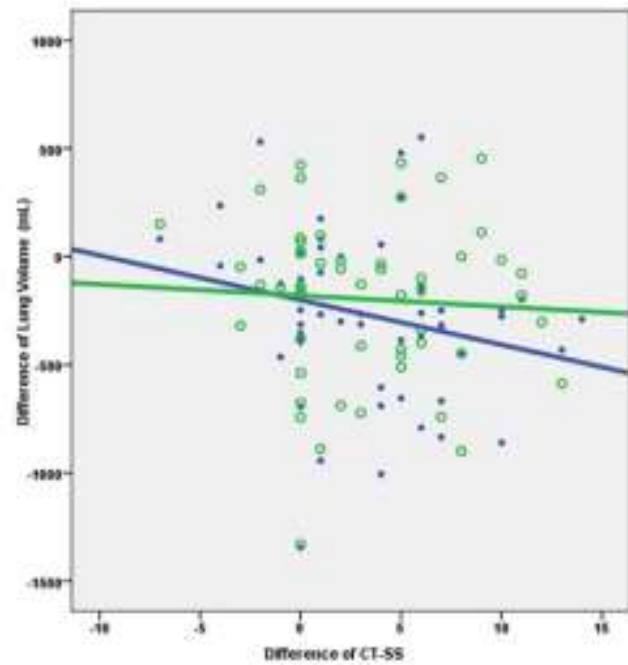

\section{OBgatang}

- vimkning

Figure 3. The difference in lung volume according to CT-SS for each lung.

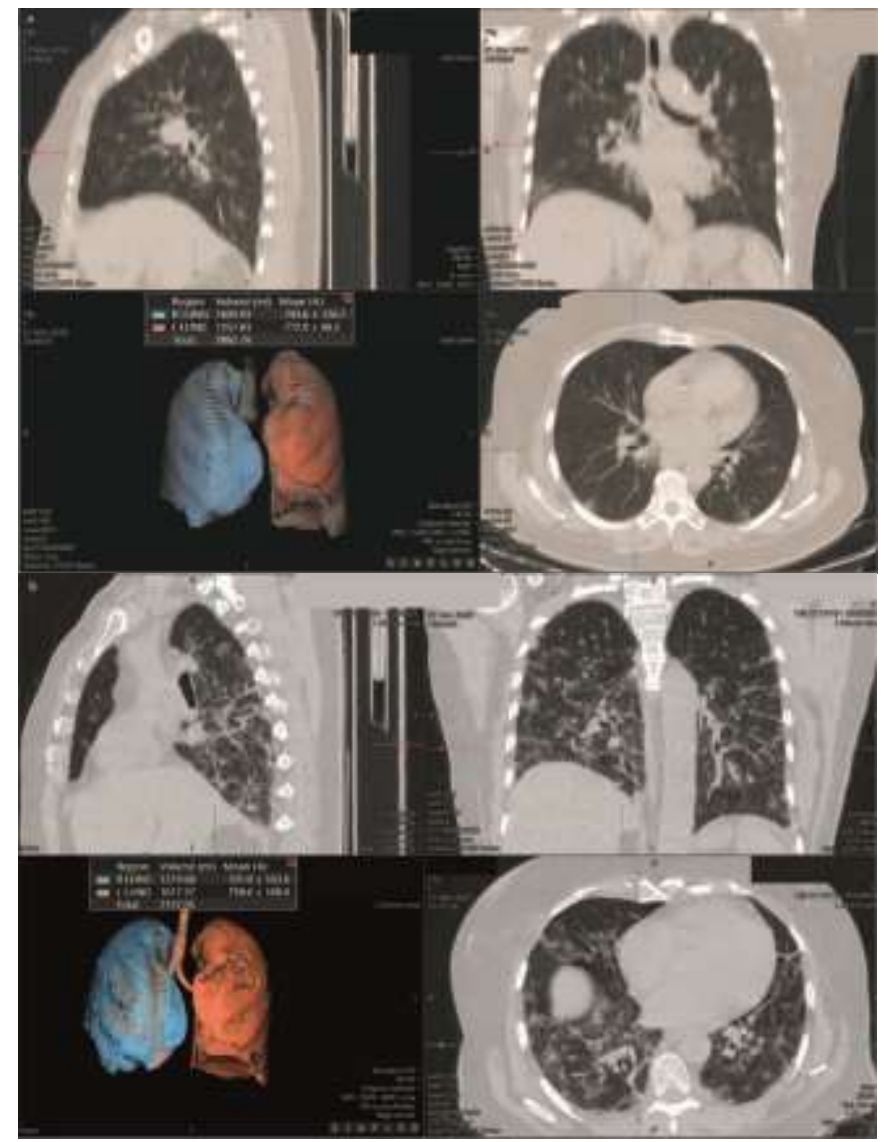

Figure 4. In initial CT of a 70-year-old Type 2 D.M. patient, CT-SS was 4 (a), while follow-up CT scans obtained 11 days later show widespread parenchymal fibrotic bands, GGOs, and CT- SS was elevated to 16 and 14 for right and left lungs, respectively. Software based image shows that both lung volumes are decreased (b). 
Table 3. Evaluation of lung volume decrease rates according to demographic features, comorbidity status, smoking history and treatment type

\begin{tabular}{|c|c|c|c|c|c|}
\hline & & & & & \\
\hline & & $\mathrm{VD}(+)$ & VD (-) & $\mathrm{VD}(+)$ & VD (-) \\
\hline & Male & $22(73.3)$ & $8(26.7)$ & $21(70.0)$ & $9(30.0)$ \\
\hline Gender $\mathrm{n}(\%)$ & Female & $19(79.2)$ & $5(20.8)$ & $18(75.0)$ & $6(25.0)$ \\
\hline & $\mathrm{p}$ & & & & \\
\hline & $<55$ & $28(77.8)$ & $8(22.2)$ & $28(77.8)$ & $8(22.2)$ \\
\hline $\begin{array}{l}\text { Age (years) } \\
n(\%)\end{array}$ & $\geq 55$ & $13(72.2)$ & $5(27.8)$ & $11(61.1)$ & $7(38.9)$ \\
\hline & $\mathrm{p}$ & & & & \\
\hline & Absence & $20(62.5)$ & $12(37.5)$ & $22(68.8)$ & $10(31.3)$ \\
\hline Comorbidity & Presence & $21(95.5)$ & $1(4.5)$ & $17(77.3)$ & $5(22.7)$ \\
\hline & $\mathrm{p}$ & & & & \\
\hline & Absence & $31(72.1)$ & $12(27.9)$ & $32(74.4)$ & $11(25.6)$ \\
\hline Hypertension & Presence & $10(90.9)$ & $1(9.1)$ & $7(63.6)$ & $4(36.4)$ \\
\hline & $\mathrm{p}$ & & & & \\
\hline & Absence & $31(70.5)$ & $13(29.5)$ & $30(68.2)$ & $14(31.8)$ \\
\hline Type 2 DM & Presence & $10(100)$ & $0(0)$ & $9(90.0)$ & $1(10.0)$ \\
\hline & $\mathrm{p}$ & & & & \\
\hline & Absence & $37(75.5)$ & $12(24.5)$ & $37(75.5)$ & $12(24.5)$ \\
\hline $\begin{array}{l}\text { COPD } \\
n(\%)\end{array}$ & Presence & $4(80.0)$ & $1(20.0)$ & $2(40.0)$ & $3(60.0)$ \\
\hline & $\mathrm{p}$ & & & & \\
\hline & Absence & $36(75)$ & $12(25)$ & $36(75)$ & $12(25.0)$ \\
\hline CAD & Presence & $5(83.3)$ & $1(16.7)$ & $3(50.0)$ & $3(50.0)$ \\
\hline & $\mathrm{p}$ & & & & \\
\hline & Never & $14(66.7)$ & $7(33.3)$ & $16(76.2)$ & $5(23.8)$ \\
\hline $\begin{array}{l}\text { Smoking status } \\
\mathrm{n}(\%)\end{array}$ & Current/Former & $11(84.6)$ & $2(15.4)$ & $9(69.2)$ & $4(30.8)$ \\
\hline & $\mathrm{p}$ & & & & \\
\hline & Outpatient & $21(67.7)$ & $10(32.3)$ & $22(71.0)$ & $9(29.0)$ \\
\hline Treatment type & Inpatient & $20(87.0)$ & $3(13.0)$ & $17(73.9)$ & $6(26.1)$ \\
\hline & $\mathrm{p}$ & & & & \\
\hline
\end{tabular}

${ }^{a}$ Fisher's Exact Test ${ }^{b}$ Pearson Chi-square Test ${ }^{*} \mathrm{p}<0.05{ }^{* *} \mathrm{p}<0.01$

Abbreviations: VD: Volume decrease, DM: Diabetes Mellitus, COPD: Chronic obstructive pulmonary disease, CAD: Coronary artery disease.

Volume decreases in each lung were evaluated related to the central and peripheral distribution pattern of lesions and the presence of GGO, consolidation, crazy paving, or linear opacities. There were no significant differences $(p>0.05$ for all)

\section{DISCUSSION}

In this study, we investigated the relationship between the severity of COVID-19 pneumonia and LV decrease in the early period. We primarily observed that the rate of LV loss might increase with the high disease severity scores. Besides the rate of lung volume loss was seen more frequently in the patients with multiple comorbidities. The volume loss of the right lung was significantly higher in severely affected cases. We recorded that there was no significant difference between lung volume loss 
and age, gender, and smoking status.

In our study, the mean interval between ICT and the FUCT examinations was $10.50 \pm 2.83$ days. Followup CT was generally performed to patients that had progressing respiratory symptoms or increasing involvement in chest X-ray images. It seems that during this brief period of around 10 days, the lung capacity of COVID-19 patients tended to decline in FUCT. In previous papers, the second week after discharge has been proposed as the ideal time for the assessment of residual parenchymal findings. ${ }^{13}$ In our study time-interval between initial and follow-up CT scan is consistent with the literature.

Savaş et al. suggested that QCT is highly related to the use of capability of the inspiratory capacity of the patient. The most important limitation of QCT volumetry is that the volume of the scanned lung alters to the amount of air inhaled at the scan. Therefore, it is possible to calculate $3 \mathrm{D}$ volume evaluation with low-dose CT scans using the same breath training protocols for the follow-up imaging. ${ }^{7}$ In our study we have provided breath training to all patients before CT evaluation. The QCT evaluation of volume loss in pneumonia patients might give practical functional data for the prediction of volume loss.

Previous researches showed that older age and male gender are important risk factors for poor outcomes in COVID-19 patients. ${ }^{14,15}$ Therewithal, in a recent study, Ardali Duzgun et al. demonstrated that the total lung volume loss was not significant in age and gender groups $(p=0.543)$. In parallel to this report, there was no significant difference in older age and male gender than the others regarding to the rate of lung volume loss in our study.

The typical radiological pattern in the earliest phase of COVID-19 pneumonia is peripherally and subpleural distributed round GGOs. ${ }^{16,17}$ In the progression phase of disease (5th-13th days of infection), GGO coexists with consolidation, septal thickening, crazy-paving pattern, linear opacities, and fibrotic bands. ${ }^{18}$ Similarly, in our study, GGO was the dominant pattern on both ICT and FUCT, and linear opacities were identified much more frequently than the other CT findings on FUCT. In accordance with the literature, the lesions were seen more frequently in the periphery of the lung on both ICT and FUCT.

The CT imaging features of fibrosis are reticular, linear opacities, and decreased lung volume, which is similar to the usual interstitial pneumonia (UIP) pattern. ${ }^{19}$ Contrary to expectations, we found no significant correlations between the rate of linear opacities in follow-up period and lung volume decrease. This inconsistency in the study may be attributed to the shortness of the interval of CTs and our patient group heterogeneity.

Iwasawa et al. reported that, smaller secondary lobes in crazy-paving pattern compared to healthy lung parenchyma which suggested local volume loss. ${ }^{8}$ In our study, there was no correlation between the incidence of crazy-paving patterns and lung volume loss.

It is stated that the consolidated and/or collapsed lung segments with features of COVID-19 pneumonia lead to a decrease in lung capacity. Therefore, there are many literature data reporting LV loss in COVID-19 patients. ${ }^{5-7}$ Ardali Duzgun et al. reported a decrease in total lung volume in all patients at the absorbtion stage of disease ( $>14$ days), although it was statistically significant only in the severe patients. ${ }^{6}$ Bozdağ et al. demonstrated volume loss by analyzing lung volumes with FUCT scans in COVID patients with severe disease. They emphasized that CT measurements of volume loss may offer objective data for both progression and long-term follow-up in COVID-19 patients. ${ }^{20}$ Similarly, in this study, LV loss on the follow-up was observed in all groups. Shen et al. demonstrated that, for the whole lung, right lung, and right lower lobe, lung volume utilizing the QCT was significantly lower in those with severe disease than in those without severe disease $(p=0.05) .{ }^{5}$ Consistent with the literature, we observed that as severity score of pneumonia increased in follow-up CT's, each LV was significantly lower. Additionally, we showed that as the disease severity increases in the right lung, volume loss is observed more frequently. This finding supports the "hyperinflammatory events occur more in the right lung compared to the left lung, which is attributed to the distribution of the virus in the right lower lobe parenchyma before and more frequently than in the other lobes in the early stage of the disease, due to the steep course of the right lower lobe bronchus" theory. ${ }^{4}$

The rate of decrease in the LV was higher in patients with comorbidities compared to other patients. Patients with Type 2 DM have chronically elevated levels of inflammation caused by multiple factors. One of them is hyperglycemia, which increases ACE2 
expression and glycation, facilitating SARS-CoV-2 entry into the cells. ${ }^{21-23}$ Additionally, hyperglycemia can induce alveolar-capillary microangiopathy. This makes collagen less susceptible to proteolysis and causes restrictive lung disease. The failure of elastic tissue in the lungs leads to the collapse of the narrow airways. ${ }^{24,25}$ For these reasons, COVID-19 patients with Type $2 \mathrm{DM}$ have a more than two-fold higher risk of developing the severe disease due to pneumonia. ${ }^{26}$ In our study, the rate of volume loss in each lung was significantly higher in Type 2 DM patients compared to the patients with other comorbidities. This is an expected result and consistent with the literature.

In post-SARS patients, those treated in the intensive care unit had a higher rate of evidences of fibrosis on CT than those who were not. ${ }^{27}$ In our study, the amount of volume decrease did not significantly differ with hospitalization status. This finding may be due to the relatively small number of patients in the study or the short time between the initial diagnosis and FUCT.

A meta-analysis showed that active smoking does not significantly associated with an increased risk of progression to severe disease in COVID-19.28 In our study, the amount of lung volume decrease, which is correlated with the severity of the disease, did not differ according to smoking status.

Our study has several limitations. The first limitation of the study was that the volume of the lung scanned during CT examination differs by the amount of air inhaled during scanning. This can be minimized by spirometry-assisted CT acquisition or specialized breath training, but assurance of maximum inspiration or expiration for image acquisition remains an important challenge for quantitative pulmonary imaging. ${ }^{29}$ The second limitation was the CT follow-up period of the patients was short in terms of predicting permanent changes in the lung parenchyma. The third limitation is distribution of comorbidities heterogeneous and the number of patients are small in all groups. Finally, the pathogenesis of volume loss due to COVID-19 pneumonia, its clinical association, and its prognostic relevance should be discussed in larger series. However, further evaluation is required to elucidate the effects of secondary pathologies on volume loss such as alveolar collapse or infection-induced parenchymal fibrosis.
In conclusion, we suggest that the main cause of volume loss due to COVID-19 pneumonia is the increased severity of the infection. It is clear that CT plays a significant role in disease diagnosis, follow-up, and prognosis once more. In addition, accurate interpretation of CT findings with quantitative data may help physicians to manage the disease.

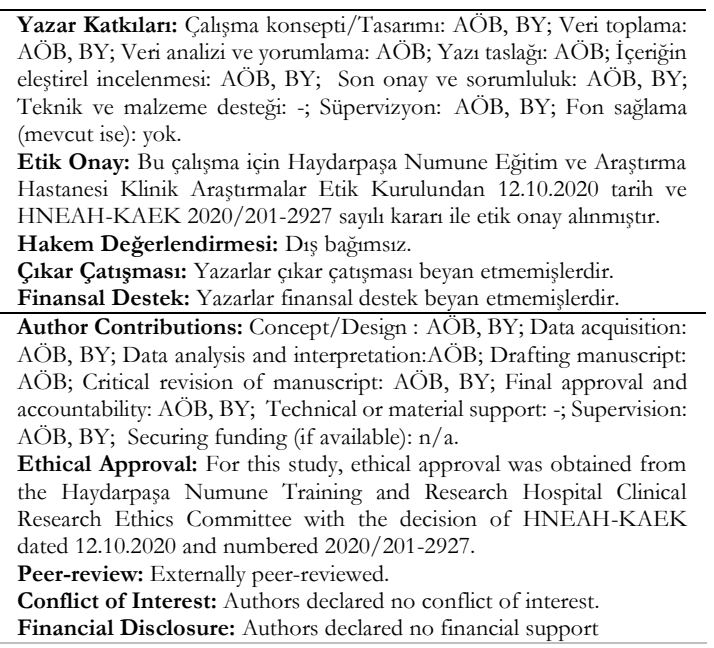

\section{REFERENCES}

1. Gavriatopoulou M, Korompoki E, Fotiou D, Ntanasis-Stathopoulos I, Psaltopoulou T, Kastritis E et al. Organ-specific manifestations of COVID-19 infection. Clin Exp Med. 2020;20:493-506.

2. Zhang T, Sun LX, Feng RE. Comparison of clinical and pathological features between severe acute respiratory syndrome and coronavirus disease 2019. Zhonghua Jie He He Hu Xi Za Zhi. 2020;43:496-502.

3. Otoupalova E, Smith S, Cheng G, Thannickal VJ. Oxidative stress in pulmonary fibrosis. Compr Physiol. 2020;10:509-47.

4. Zhou S, Wang Y, Zhu T, Xia L. CT features of coronavirus disease 2019 (COVID-19) pneumonia in 62 patients in Wuhan, China. Ajr Am J Roentgenol, 2020;214:1287-94.

5. Shen C, Yu N, Cai S, Zhou J, Sheng J, Liu K et al. Quantitative computed tomography analysis for stratifying the severity of Coronavirus Disease 2019. J Pharm Anal. 2020;10:123-9.

6. Ardali Duzgun S, Durhan G, Basaran Demirkazik F, Irmak I, Karakaya J, Akpinar E et al. AI-Based quantitative $\mathrm{CT}$ analysis of temporal changes according to disease severity in COVID-19 pneumonia. J Comput Assist Tomogr. 2021;45:970-8.

7. Savaş R, Öz Özcan A. Evaluation of lung volume loss with 3D CT volumetry in COVID-19 patients. Diagn Interv Radiol. 2021;27:155-6. 
8. Iwasawa T, Sato M, Yamava T, Sato Y, Uchida Y, Kitamura $\mathrm{H}$ et al. Ultra-high-resolution computed tomography can demonstrate alveolar collapse in novel coronavirus (COVID-19) pneumonia. Jpn J Radiol. 2020;38:394-8.

9. Robbie H, Wells AU, Jacob J, Walsh SLF, Nair A, Srikanthan A et al. Visual and automated CT measurements of lung volume loss in idiopathic pulmonary fibrosis. AJR Am J Roentgenol. 2019;213:318-24.

10. Rubin GD, Ryerson CJ, Haramati LB, Sverzellati N, Kanne JP, Raoof $\mathrm{S}$ et al. The role of chest imaging in patient management during the COVID-19 pandemic: a multinational consensus statement from the Fleischner Society. Chest. 2020;158:106-16.

11. Hansell DM, Bankier AA, MacMahon H, McLoud TC, Müller NL, Remy J. Fleischner Society: Glossary of terms for thoracic imaging, Radiology. 2008;246:697-722.

12. Yang R, Li X, Liu H, Zhen Y, Zhang X, Xiong Q et al. Chest CT severity score: an imaging tool for assessing severe COVID-19. Radiol Cardiothorac Imaging. 2: e200047.

13. Liu D, Zhang W, Pan F, Li L, Yang L, Zheng D et al. The pulmonary sequalae in discharged patients with COVID-19: a short-term observational study. Respir Res. 2020;21:125.

14. Zhou Z, Chen P, Peng H. Are healthy smokers really healthy? Tob Induc Dis. 2016;14:35.

15. Park JE, Jung S, Kim A, Park JE. MERS transmission and risk factors: a systematic review. BMC public health. 2018;18:574.

16. Chung M, Bernheim A, Mei X, Zhang N, Huang M, Zeng X et al. CT imaging features of 2019 novel coronavirus (2019-nCoV). Radiology. 2020;295:202-7.

17. Pan F, Ye T, Sun P, Gui S, Liang B, Li L et al. Time course of lung changes at chest CT during recovery from coronavirus disease 2019 (COVID-19). Radiology. 2020;295:715-21.

18. Wang K, Kang S, Tian R, Zhang X, Wang Y. Imaging manifestations and diagnostic value of chest CT of coronavirus disease 2019 (COVID-19) in the Xiaogan area. Clin Radiol. 2020;75:341-7.

19. Martinez FJ, Collard HR, Pardo A, Raghu G, Richeldi L, Selman M et al. Idiopathic pulmonary fibrosis. Nat Rev Dis Primers. 2017;3:17074.

20. Bozdağ M, Savas R. Chest CT imaging features of COVID-19-related pulmonary fibrosis: A case report. Iran J Radiol. 2021;18-1.

21. Bornstein SR, Dalan R, Hopkins D, Mingrone G, Boehm BO. Endocrine and metabolic link to coronavirus infection. Nat Rev Endocrinol. 2020;16:297-8

22. Ceriello A. Hyperglycemia and the worse prognosis of COVID-19. Why a fast blood glucose control should be mandatory. Diabetes Res Clin Pract. 2020;163:108186.

23. Rajpal A, Rahimi L, Ismail-Beigi F. Factors leading to high morbidity and mortality of COVID-19 in patients with type 2 diabetes. J Diabetes. 2020;12:895908.

24. Pitocco D, Fuso L, Conte EG, Zaccardi F, Condoluci $\mathrm{C}$, Scavone $\mathrm{G}$ et al. The diabetic lung--a new target organ?. Rev Diabet Stud. 2012;9:23-35.

25. Kolahian S, Leiss V, Nürnberg B. Diabetic lung disease: fact or fiction? Rev Endocr Metab Disord. 2019;20:303-19.

26. Kumar A, Arora A, Sharma P, Anikhindi SA, Bansal $\mathrm{N}$, Singla $\mathrm{V}$ et al. Is diabetes mellitus associated with mortality and severity of COVID-19? A meta-analysis. Diabetes Metab Syndr. 2020;14:535-45.

27. Antonio GE, Wong KT, Hui DS, Wu A, Lee N, Yuen $\mathrm{EH}$ et al. Thin-section CT in patients with severe acute respiratory syndrome following hospital discharge: preliminary experience. Radiology. 2003;228:810-5.

28. Lippi G, Henry BM. Active smoking is not associated with severity of coronavirus disease 2019 (COVID19). Eur J Intern Med. 2020;75:107-8.

29. Chen A, Karwoski RA, Gierada DS, Bartholmai BJ, Koo CW. Quantitative CT analysis of diffuse lung disease. Radiographics. 2020;40:28-43. 